Book Review

\title{
Powell, Jason, Jacques Derrida: A Biography'
}

Marko Zlomislic

A s if it will ever be possible to write Derrida's biography. Who would have the strength to settle the account and to take into account all the threads and themes and folds that will have taken place between what is announced as the date of Derrida's birth and declared as the time of his death?

Powell should be praised for making an excellent attempt that brings biographical material from other sources together in one volume. Powell presents his account of Derrida's life into periods: "Algeria," "Paris and the ENS," "The 1980's," and so on. He provides good summaries of Derrida's major works with very good discussions of Derrida's philosophical and literary sources.

Powell states that he had no access to Derrida's letters and personal papers. ${ }^{2}$ This is understandable. However, given that he was writing a complete biographical overview, Powell could have consulted the Derrida archive housed at the University of California, Irvine. ${ }^{3}$ This material clearly shows the development of Derrida's thought. It reveals that Derrida was a careful and meticulous researcher and scholar with a first rate understanding of the history of philosophy. The archive also reveals Derrida's lesser known sources such as Spinoza and Malebranche. Those who only consider Derrida's published works do not have a proper context for understanding the full dimensions of Derrida's project.

Powell passionately defends Derrida from the attacks of critics and mis-readers such as John Searle and Roger Scruton. It is clear that he admires Derrida but in many places Powell relies on the interpretations of Bernasconi and Caputo. This reliance is problematic because it prevents Powell from getting to the heart of Derrida's philosophy. I have located a few points of contention that require a response.

Powell refers to Derrida's method as "basically Heideggerian deconstruction."4 Following Bernasconi, Powell believes that Derrida followed

\footnotetext{
${ }^{1}$ New York: Continuum Press, 2006. 250 pp.

${ }^{2}$ Ibid., 6.

3 Jacques Derrida, Papers, MS-C01, Special Collections and Archives (The UC Irvine Libraries, Irvine, California).

${ }^{4}$ Powell, Jacques Derrida: A Biography, 1.
} 


\section{JACQUES DERRIDA}

Levinas "in his ethics of the other." 5 Powell speaks of "Derrida's new Platonism." He believes that there is a continuity between Nietzsche and Derrida. ${ }^{7}$ He claims that Derrida's Glas, "has all the features of being the work of a beginner." Powell speaks of Derrida's "belated study of Heidegger" and asks why Derrida waited until the late 1970's and 1980's to speak on Heidegger. ${ }^{9}$ These mistakes need to be corrected.

Simply put, in keeping with his aporetic turn, Derrida, as a first rate philosopher seeks to know the truth of the becoming of all things by deconstructing demonstrations, disseminating definitions, differancing distinctions and deciding over the abyss of undecidability. This method constitutes Derrida's unique contribution to philosophical analysis.

Derrida differs from Heidegger who stayed within the hermeneutic circle and fundamental ontology such that his philosophy remained closed to the possibility of responsibility, pure gift and decision. Derrida shows how ethical choice is made possible by the aporia of undecidability.

Derrida differs from Plato who sought to suppress the pharmakon and its pharmaceutical excess. In refusing to see the undecidability of the pharmakon and what disseminates from it, Plato remained convinced of the purity of his philosophical operation even when the evidence indicated otherwise.

While Derrida was influenced by Levinas there are essential differences in their philosophies. Levinas keeps the metaphysics of presence in the face that speaks. Derrida has difference and dissemination leading to a deconstruction of the metaphysics of presence. In Otherwise Than Being, Levinas focuses on the passivity that precedes choice. Derrida on the other hand, explores the choice that comes out of undecidability. In Derrida's words from an interview entitled, "As if it were possible," "I am simply trying to pursue with some consequence the thinking that for years has been engaged with the same aporias. The question of ethics, of rights and politics did not spring forth unexpectedly as from a bend in the road." 10

While Derrida can be said to belong to a Nietzschean lineage that argues for unlimited perspectives, he will be critical of Nietzsche for not getting beyond the "will to power" to a personal responsibility for decisions.

Derrida's Glas works out various models of glorification. This text can be seen as a masterpiece of philosophical analysis. Derrida develops his philosophy of glory as a pure giving with its ethics of responsibility to responsibility. In Glas Derrida meditates on the dialectical model of glorification with Hegel, the inversion model of glory with Genet and develops

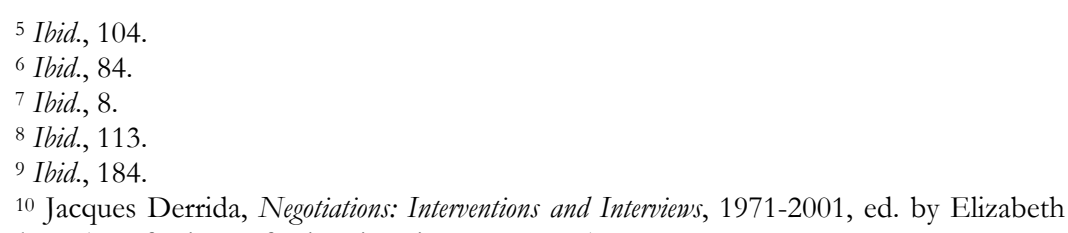
N. Rottenberg (Stanford: Stanford University Press, 2002), 360. 
his own mourning model. To my mind, Derrida has a clear grasp of the philosophical, religious and literary tradition that he is exploring in Glas. It makes no sense to refer to this work as a beginner's attempt.

The archival material at Irvine indicates that Derrida was studying Heidegger as early as 1954. From 1961-1962 Derrida gave a seminar on Heidegger entitled, "Le Monde Chez Heidegger" From 1963-1964 he gave another seminar on Heidegger entitled 'Erreur et Errance: Heidegger.' One cannot claim comprehensiveness while ignoring material and information that was readily available.

While Powell is correct to point out that Derrida was first "received by the American academic establishment as a literary writer."11 Derrida himself provides an explanation of his American reception. Derrida writes, "Literary theory, especially in America was more ready to listen to arguments and strategies to get behind reason's back than institutional inscriptions of philosophy ... the politics of these departments ... were in this sense more philosophical."12 While Powell does list the book from which Derrida's words were taken in his Bibliography, he does not go far enough in allowing Derrida to defend his own position. Powell misses many important quotes from Derrida that would have been his book comprehensive in scope and detail.

Given that Derrida was accused by the analytic establishment of destroying philosophy, Powell could have said more about Derrida's passionate defense of philosophy. Derrida believed in "keeping the field of tradition open."13 Perhaps this is the reason the analytic tradition opposed Derrida who was against "a certain stabilizing or stabilized coding of hierarchy."14 Perhaps this is what Powell had in mind when he writes that analytic philosophy "has as its telos the establishment of a universal culture for a static, totalitarian universal civilization."15 I would have liked to see more analysis of this point and its relation to the attacks against Derrida from analytic philosophers who failed to take the advice of Wittgenstein when they wrote about things they did not fully read or understand.

A separate history needs to be written here that would examine the continental/analytic divide. Powell begins this task by pointing out that Derrida's "students and colleagues suffered the same treatment at the hands of the establishment."16 I can attest to this mistreatment when I was prevented from completing my work on Derrida's ethics and had to transfer to another institution. Other friends who were working on Derrida were subject to the same totalitarian tactics that Powell describes so well.

Given that Powell has the word "biography" in the title of his book, I would have liked to see Powell say more about Derrida's life and the man that he was. My own experience is that Derrida was a generous, kind man and a

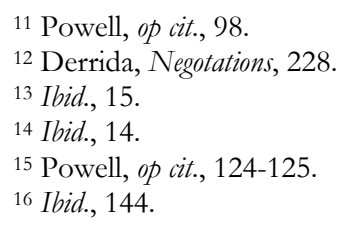




\section{JACQUES DERRIDA}

decent human being. Attending his seminar in Paris in 1992 was a transformative and life changing experience. He responded to my letters and questions with hand written pages that I will always cherish. He encouraged my work with the wisdom of a dedicated teacher. He met with me when I was writing my introductions to the Croatian translations of The Other Heading and Specters of Marx. Reading Powell's book was a worthwhile experience that has brought back many memories. The Derrida I remember does not resemble the picture chosen for the cover of Powell's book. This fills me with sadness. I recommend this book to anyone beginning to read Derrida and to those who continue to read him.

I would hope that someone will attempt to write about the man and his life rather than his works in a way that avoids the calculation that cancels out the future. Powell is correct in noting that such a work would exceed several volumes. This is the crisis and aporia of biography where one struggles to archive a legacy while retaining the secret of an undecidable reserve.

Liberal and Media Studies, Conestoga College Institute of Technology and Advanced Learning, Canada

\section{References}

Derrida, Jacques, Negotiations: Interventions and Interviews, 1971-2001, ed. by Elizabeth N . Rottenberg (Stanford: Stanford University Press, 2002).

Derrida, Jacques, Papers, MS-C01, Special Collections and Archives (The UC Irvine Libraries, Irvine, California).

Powell, Jason, Jacques Derrida: A Biography (New York: Continuum Press, 2006). 